\title{
Joachim Paech
}

\section{Response to the Apertúra Questionnaire 2018}

\section{Szerzô}

Prof. Dr. Joachim Paech (1942, Berlin) színháztudományt, germanisztikát és filozófiát tanult a berlini Freie Universitäten. Ugyanitt szerzett doktori fokozatot 1974-ben múvészettudomány szakon, témája az orosz forradalom színháza volt. 1975 és 1988 között az Universität Osnabrück médiatudomány szakán tanított, itt írta habilitációját is 1978-ban. 1988-89-ben a belgiumi Université catholique de Louvain és a freiburgi Albrecht Ludwigs-Universität vendégprofesszora, 1989-tôl pedig egészen 2007-ig az Universität Konstanz professzora médiatudomány szakon. Kutatási területe a film elmélete és története, a filmi, az irodalmi, a hagyományos múvészetekhez és az új médiához köthetô intermedialitás. Fontosabb munkái - PASSION oder Die EinBILDungen des Jean-Luc Godard. Frankfurt, 1989. - Literatur und Film. Második kiadás. Stuttgart, 1997. Menschen im Kino. Film und Literatur erzählen. Stuttgart - Weimar, 2000. (Anne Paech-hel közösen) Der Bewegung einer Linie folgen... Schriften zum Film. Berlin, 2002.

https://doi.org/10.31176/apertura.2018.14.1.5 


\section{Joachim Paech}

\section{Response to the Apertúra Questionnaire 2018}

The traditional role of universities is undergoing a transformation

I hope so. And what is their "traditional role"? From the moment universities were born, they have been changing constantly. University research and teaching have not only exerted their effects on (social) reality, they have necessarily changed the institution itself. In the context of technical modernity, owing its success largely to the decisive role played by universities, C. P. Snow spoke, in the 1950s, of the superiority of natural sciences, in contrast to the critical humanities, which were viewed as an obstacle in the modernization process. Scientific research is meant to be applied, it is in the focus of economic interests and political power. The humanities are interested in the "content", ultimately in thinking itself, and are exposed to the suspicion that they are dealing only with themselves. Already at the moment of the formation of the discipline in the 19th century, literary studies were accused of concentrating - just like the literary hero Don Quixote on fictional texts lacking truth, rather than dealing with the blueprints of engineering sciences, with which one could build, after all, bridges, cars or aircrafts (and wage wars). Friedrich Kittler, who was originally a literary scholar, saw that the many ghosts haunted by literature in the Romantic era were actually hidden "media", which were supposed to help illustrate the new invisible energies, such as gas and electricity. In addition, they materialized as personified spiritual media, usually in the form of young women, true to McLuhan's motto according to which the content of a medium is always a (different) medium (e.g. writing in a book, spoken language on the radio, etc.). Modern technology has not made the humanities superfluous, but on the contrary, it has challenged their critical potential. Compared to technical positivism, their cause is the social memory of the past, the only point from which a future is imaginable. Narratives make the connection between the remembered past and a conceivable future. They have to be retold again and again hermeneutically in the present, they have to be read critically and communicated through the media. Whoever controls this process of "cultural memory" (history) takes possession not only of mental but also of material culture. Critical humanities are repeatedly attacked because of their power over knowledge and consciousness. The task of the humanities is to use critical discourse and an independent, truth-bound science to counteract all attempts of political, economic, etc. exploitation.

The history of film studies is a good example for the above mentioned problem, faced by universities, especially humanities and cultural studies. Although movies have existed since the end of the 19th century, the academic discourse on film studies was established only in the mid- 
1960s. The importance of film is obvious in a particularly vivid communication of contemporary narratives, ranging from ideologies to propaganda, yet - or for that very reason - it took a long time until the study of film entered universities. Film was not at all estimated as an art form but criticized merely as a popular medium. Film could become the subject of university research only when it became easily accessible, from the 1960s in the US and from the mid-1970s in Europe. While American universities could take advantage of the film archives of major companies, in Europe films became available for the seminars only by recording them from television (diverse film schools, where practical training is conducted in archives, are in a different position). Films had to be available for analysis in order to serve as objects of theoretical and aesthetical investigations at universities, while universities had to give in, transform and accept technical media - and popular culture in a broader sense - as objects of research (cf. the unfortunate discussion about "literary adaptations" as destructing traditional literature). Currently, new digital media, especially PCs, have largely penetrated or revolutionized traditional universities. "Film" has become a ubiquitous, multimedia form of moving images on digital screens. The humanities today are challenged by reflecting on the technological (or material) aspects of the media (literary studies has long avoided thinking about the book as a material condition of its medium and the form of its content). Social and mass media are about to build our reality according to their image, or rather the image of those who exercise political and economic power through them - with effects even at the universities. Lies have become commonly practiced media tools to an unprecedented extent, and this is why thinking must intervene as a form of intellectual resistance (including an intervention against the staring look on the smartphone display). The humanities are summoned to organize the resistance of the free and independent spirit.

\section{Interdisciplinarity and film}

The call for interdisciplinary research is the response to the fact that in our days, with few exceptions, research within a too narrow disciplinary and methodological framework is hardly possible or meaningful (if it ever was). The discomfort with interdisciplinarity is due partly to the uncertainty of a too openly defined field, where scientific competence and areas of research no longer converge. Academia requires lifelong learning by all involved. This, however, also means a kind of loss of control, since the subject of research can no longer be delimited in its traditional context, and diffuses into seemingly arbitrary "super-disciplines". But how else should "film" be treated if not in meaningful cooperation with intellectual, academic, cultural, social, medial (technological) etc. perspectives? This does not mean that under certain circumstances it is not possible to set priorities for research design. But while film is always an economically and socially relevant technical medium, it is also a literary narrative, a performing art and a musical composition. Film has historically created various forms of its medium. Researching these forms becomes increasingly important as these forms dissolve into the general data constellation of the 
motion picture, up to the point where film becomes an algorithm that differentiates it from other possibilities of media. In the feared interdisciplinary loss of "film" as a research object, "film" corresponds to its actual intermedial disappearance in the "data stream". Aesthetics and hermeneutics as well as text and media analysis of films will continue to be justified. But the main question asked currently of all film studies is "what is film today?" And this question can, in my view, be answered only in the wider (interdisciplinary) framework of cultural and media studies. At the beginning of the 1960s André Bazin had already asked "qu'est-ce que le cinéma?" This question is currently to be answered anew for all forms of film studies.

\section{Art cinema and popular films}

It is estimated that about $80 \%$ of the worldwide silent film production was destroyed after utilization in the film theatres. At the beginning films were not worth to be preserved and their archiving was too expensive. When film archives emerged in the early 1930s in England, Germany and the United States (at the major studios), the films stored were the ones that were suspected of being art because of their technical innovations, for being literary adaptations, or because their directors ("authors") had a certain reputation. Later, these films from the "stock" were available to the television. At the same time, the film industry has always avoided getting too close to art because of its potentially negative consequences to popularity and commerce. Artistic films serve a "special interest" audience, while the costly block busters must be popular. A study of films that operates exclusively on "good films" among people with "good taste" misses the idea of film understood as a mass medium. Film today is an extraordinarily diverse product (see above, "what is film?"), so successful film studies should cover all facets of film in all its places (cinema, television, video, internet). I myself have selected films as cultural texts in the context of certain cultural developments; what matters is their specific contribution to the respective topic of my work.

\section{The future of film studies}

In the future film studies will be either a part of general interdisciplinary media studies and intermediality research and / or will be understood as the archeology of the moving image.

\section{Film education}

Since film studies established itself at the universities as a discipline, film has been treated as an object of history and theory - defined differently than in schools providing practical training in film. Film history, film aesthetics, film theory, even film philosophy needs methods that have 
been adopted from other discourses (iconography, text theory, psychoanalysis, etc.) or in the framework of actual academic trends (semiotics, structuralism, etc.). There has never been an inherent method specific for film studies; the notion of "specifically cinematic" has turned out to be a mistake, instead, film history is based on literary studies for its use of authors, genres, etc., while image analysis uses iconographic or semiotic approaches. Why not? This promotes the integration of film as a subject of research into the broad spectrum of the university, where it stirs conflicts of interest even in some remote corners of the humanities.

\section{Conclusion}

Film studies, as well as art or literary studies, still has its significance for the cultural heritage and the insight into the relationship between national and international film productions. It is urgently required in the context of a general media science in dealing with the ever-growing flood of images and the influence of the so-called "social media", where films made by their users are circulating in large numbers as videos and streams. Professional cinema films as well as private porn films or party streamings etc. are manufactured, sent and received by smartphones. All educational institutions face an immense challenge and task regarding this phenomenon.

The question of what film science will look like in thirty years' time can only be answered in terms of the dynamic changes in its complex subject. At the beginning of the twentieth century, the Lumière brothers wanted to give up their invention, the film, because they no longer believed in its future. Luckily, they were wrong. Television, video and the Internet have not threatened film but its original "home", the film theatre. Nowadays film is the glamorous event of film festivals and Oscar awards as well the everyday serial consumption of TV- series that can take place anywhere with WiFi access. Film studies will continue to have its justification, and remain to be necessary if it continually redefines its role in a changing society. It will have to transform permanently with and in universities. 
(C) Apertúra, 2018. Ôssz | www.apertura.hu

webcím: https://www.apertura.hu/2018/osz/paech-response-to-the-apertura-questionnaire-2018/

https://doi.org/10.31176/apertura.2018.14.1.5

\section{Q)opertúro}

